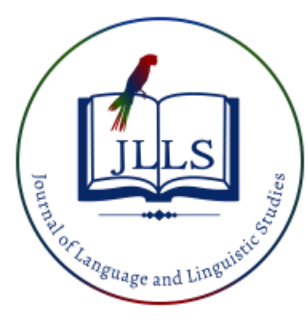

Available online at www.jlls.org

JOURNAL OF LANGUAGE AND LINGUISTIC STUDIES

ISSN: $1305-578 \mathrm{X}$

Journal of Language and Linguistic Studies, 16(4), 1854-1868; 2020

\title{
Looting leads to shooting: A pragma-dialectical analysis of President Trump's argumentative discourse on Floyd's death
}

\author{
Gibreel Sadeq Alaghbary a 1 iD \\ ${ }^{a}$ Qassim University, Buraydah, Saudi Arabia
}

\section{APA Citation:}

Alaghbary, G. S. (2020). Looting leads looting leads to shooting: A pragma-dialectical analysis of President Trump's argumentative discourse on Floyd's death. Journal of Language and Linguistic Studies, 16(4), 1854-1868.

Submission Date: $16 / 07 / 2020$

Acceptance Date:02/11/2020

\begin{abstract}
This study aims at problematizing President Trump's argumentation in response to the protesters' demands for justice, racial equality and police reforms over the killing of George Floyd. In his first reaction, Trump used mild rhetoric that frustrated and galvanized the angry mobs. In response to escalating protests, Trump escalated his own rhetoric. Calling into question the character and credibility of the protesters, Trump labelled the protesters "thugs" and "terrorists", alluded to the deployment of the Military, and tweeted "when the looting starts, the shooting starts". Pragma-dialectical analysis of Trumps' response reveals that rational argumentation yields to derailed strategic maneuvering involving name-giving, ad baculum and ad hominem fallacies. Trump makes a dialectical shift from persuasive logic to fear arousing and threat making tactics in order to coercively hold up demonstrations and enforce compliance, and later shifts from persuasion to eristic discourse. He politicizes his response by accusing the media of fomenting hatred and anarchy, and by blaming the mayhem on his democratic rival, who is ridiculed and personally abused. These are irrelevant argumentative moves in the socio-political context as well as in the context of the persuasion discourse.
\end{abstract}

(C) 2020 JLLS and the Authors - Published by JLLS.

Keywords: argumentation; Donald J. Trump; fallacies; Floyd; Twitter

\section{Introduction}

Argumentation is prototypically a verbal (takes place by means of language), social (directed at other people), and rational (based on reasoning) activity "aimed at convincing a reasonable critic of the acceptability of a standpoint by putting forward a constellation of propositions justifying or refuting the proposition expressed in the standpoint" (Eemeren \& Grootendorst, 2004). Argumentation theorists are concerned with the analysis of the structure of argumentation, the "unexpressed elements of argumentative discourse," and fallacies in argumentation (Eemeren \& Grootendorst, 2004, p. 3). The term fallacy is used in the logic literature to refer to an argument that seems valid but is logically invalid (Eemeren \& Grootendorst, 2004).

\footnotetext{
${ }^{1}$ Corresponding author.

E-mail address: g.alaghbary@qu.edu.sa
} 
Fallacious arguments are arguments in which logical argumentation makes way for scare tactics. The term scare tactics covers arguments that make use of various kinds of appeals to fear, threats and force (Walton, 2000). A fear appeal argument is as "a kind of argument used to threaten a target audience with a fearful outcome (most typically the outcome is the likelihood of death), in order to get the audience to adopt a recommended response" (Walton, 2000, p. 1). In these arguments, the arguer appeals to a certain fear in the receiver and invokes relevant fearful consequences in order to steer the receiver in a particular direction. If the cause is good, we describe the appeal to fear as non-fallacious. If the arguer, however, appeals to a fear in the audience for personal gains and uses logically weak reasoning strategies instead of presenting convincing evidence, the argument is manipulative and fallacious (also known as argumentum ad metum).

Like fear appeal arguments, threat appeal arguments are fallacious if the arguer "substitutes a threat of force for evidence" (Salmon, 2013, p. 99) and argues from consequences instead of arguing from evidence in the interest of intimidating the audience into compliance. Fallacious threat appeal arguments are also called argumentum ad baculum, meaning argument to the stick/club (Walton, 2000). The speech act of threat may be made directly (an overt ad baculum argument) or indirectly (a covert ad baculum argument). In either case, it has to meet three essential conditions: preparatory conditions (the addressee has reason to believe that the speaker can bring about the threat), a sincerity condition (both parties presume that the addressee would want to avoid the occurrence of the threat and take steps to do so), an essential condition (the speaker is making a commitment to see to it that the threat will occur unless the addressee complies with the speaker) (Walton, 2000). The last condition makes the threat credible. The credibility of the proponent of the threat also depends on their "past willingness to carry out threats" and their "reputation for truthfulness" (Walton, 2000, p. 121). Related to credibility is the legitimacy of a threat, which is a function of the "social context in which a threat is made, and the relationship of the respondent and the proponent in some system of contractual and social norms" (Walton, 2000, p. 179). A speech act of threat is, therefore, evaluated against these three conditions as well as the credibility and legitimacy normative requirements.

These scare tactics are quite common in political discourse, which is expected to be persuasive in nature. Speeches, press conferences, election debates and even argumentation on the "new social media" are examples of persuasive political argumentation (Wodak, 2015) which typically involve logical reasoning supported by evidence. The arguments can derail, however, into adversarial verbal struggle (also known as eristic dialogue) where an arguer demonizes an opponent (a fallacy known as ad hominem fallacy) instead of attacking their argument. Political argumentation may also comprise fallacious fear or threat appeal arguments that involve a dialectical shift from logical reasoning and persuasive logic to fear arousing or threat making tactics in order to coercively hold up opposition and enforce compliance.

\subsection{Literature on President Trump's political rhetoric}

Donald John Trump, the 45th president of the United States, has an "unconventional political style" (Hall, Goldstein, \& Ingram, 2016, p. 71) which has attracted the attention of stylisticians and critical discourse analysts during his current term as President (e.g., Ott, 2017; Kayam, 2018; Clark \& Grieve, 2019). Golshan (2016) argues that Trump's political discourse features many of the qualities of conversational speech such as unfinished sentences, unorganized thoughts, repetition and digressions. To this list, Hall, Goldstein and Ingram (2016) add the "use of gesture to critique the political system and caricature his opponents" (p. 71). This caricaturing of opponents by embodying their bahavior is foreign to the "normative gestural behavior for politicians seeking the Oval Office" (Hall, Goldstein, \& Ingram, 2016, p. 74). 
Trump's political discourse contains other rhetorical idiosyncrasies that make him understood by the majority of electorates. Wang \& Liu (2018) report that Trump's language readability level in debates is "close to fifth-grade level" (p. 314) and reaches the ninth level in campaign speeches. Kayam (2018) confirms these findings and reports that Trump speaks at "a fourth- to fifth-grade level" (p. 86). This is a "readability level that is lower than the level of the average adult in the US", which means that Trump "is understood by almost every American voter" (p. 74).

In addition to his political speeches, Trump's Twitter account (@ realDonaldTrump) has been subject to critical examination by scholars and media critics. Many of these studies have been top-down, focusing on formal features of Trump's rhetoric, such as misspellings in his tweets (Monggong, 2017), lexical choice and unconventional grammar (Robinson, 2019). Clark and Grieve (2019), however, offers a corpus-driven description of variation and change in the style of Trump's tweets between 2009 and 2018. The study spans Trump's presidential campaign and presidential term and seeks to describe Trump's (evolving) communication strategy on Twitter.

The present study in an extension of the growing literature on President Trump's rhetoric on Twitter. It examines Trump's response to the death of George Floyd, which has been published almost entirely in the form of tweets on Trump's Twitter account. Unlike the previous studies, the focus of analysis is on supra-sentential components of Trump's political rhetoric. The study examines Trump's argumentative moves (and strategic maneuvering) in addressing angry protesters' demands of justice, racial equality and police reforms.

\section{Materials and method}

\subsection{Materials}

This study covers the eighteen-day period between May 25, 2020 (the date of George Floyd's death) and June $12^{\text {th }}$ (the day when President Trump takes 'relevant' action by announcing his administration is finalizing an Executive Order on police reform). The material for analysis is Trump's discourse on George Floyd's death and on the consecutive days and nights of mass protests around the country demanding justice for Floyd and an end to racism, inequality and police practices. The texts are 51 in number and are mainly retrieved from President Trump's official twitter account @ realDonaldTrump.

President Trump's response breaks down into three categories. The first category includes Trump's response to George Floyd's death. This stage comprises six tweets, two speeches and one conversation with a reporter in a press conference. The texts in this category are smaller in number but longer in length. These texts were produced between May 28, 2020 and June 2, 2020. The second category comprises Trump's tweets on the nationwide rallies opposing police violence and demanding justice and change. This group includes 18 tweets published between May 29, 2020 and June 7, 2020. The third, and last, category, includes 3 tweets on the media and 21 tweets on Trump's democratic rival published between May 29, 2020 and June 12, 2020.

\subsection{Method}

This study examines President Trump's use of scare tactics in responding to Floyd's death and the subsequent popular protests about racism and police brutality. To meet its analytical demands, the study draws upon the pragma-dialectical approach to argumentation that is credited to the Dutch professors of communication van Eemeren and Grootendorst $(1992,2004)$. The approach has two dimensions. The first one is the pragmatic dimension, which is concerned with, among other things, utterances that have a communicative force and perform an act such as threatening. These utterances are known as speech 
acts (Austin, 1961; Searle, 1970). The second dimension is the dialectical dimension, which is concerned with the study of argumentation strategies and the detection of fallacies in arguments in different kinds of discourse types (Eemeren \& Grootendorst, 1992).

Following pragma-dialecticians, I will start by identifying the manipulative tactics in Trump's argumentation. I will then examine the level of fear created or threat made against the truth of the claims in order to determine the validity or fallaciousness of the argumentation. I will also identify the essential conditions of any threats made, and establish their credibility and legitimacy in relation to the situational context and the normative rules governing the relationship between the proponent and the respondents. Any strategic maneuvers deployed by Trump will also be highlighted and analyzed as a sequence of practical reasoning following Walton (2000).

\section{Results}

George Floyd, an African-American, was killed on Monday May 25, 2020, aged 46. A video of Floyd's death shows him handcuffed, under the knee of a white Minneapolis police officer pleading that he could not breathe. The officer continued to kneel on Floyd's neck for about nine minutes until Floyd stopped breathing. Three days later, President Trump's first reaction, in response to a question by a reporter, was:

I feel very, very badly. That is a very shocking sight ... I have asked the attorney general, FBI, and the attorney general to take a very strong look and to see what went on because that was a very, very bad thing that I saw. I saw it last night and I didn't like it. (1266110033827377153, May 28, 2020)

Trump's first response to the brutal killing of Floyd substantiates the findings of previous research on his rhetoric (e.g., Golshan, 2016; Wang \& Liu, 2018; Kayam, 2018). Trump, although using a "genuine speaking style" (Wang \& Liu, 2018, p. 315), described the murder as "a very, very bad thing" which he "didn't like". Speaking at "a fourth- to fifth-grade level" (Kayam, 2018, p. 86) in response to a ruthless manslaughter in a public place frustrated the demonstrators. Protests escalated, and Trump published his first two tweets on Floyd's death.

1 At my request, the FBI and the Department of Justice are already well into an investigation as to the very sad and tragic death in Minnesota of George Floyd... (1265774767493148672, May 28, 2020, $1: 39$ AM)

2 ... I have asked for this investigation to be expedited and greatly appreciate all of the work done by local law enforcement. My heart goes out to George's family and friends. Justice will be served! (1265774770877902848, May 28, 2020, 1:39 AM)

Floyd's death is now "sad and tragic" (tweet 1) and Trump made reference to his request to the FBI and Department of Justice to expedite the investigation. The sentences are complex and vocabulary appropriate to the situation. However, Trump 'great appreciation' of the work of the police (tweet 2), despite all the criticism they had received, disappointed the protesters. Protests went nationwide. Law enforcement forces started dispersing crowds and protesters clashed with the police. Some of the protests escalated into riots and some protesters started vandalizing property and looting shops. Trump responded with his most controversial tweets:

3 I can't stand back \& watch this happen to a great American City, Minneapolis. A total lack of leadership. Either the very weak Radical Left Mayor, Jacob Frey, get his act together and bring the City 
under control, or I will send in the National Guard \& get the job done right....(1266231100172615680, May 29, 2020 7:53 AM)

4 .... These THUGS are dishonoring the memory of George Floyd, and I won't let that happen. Just spoke to Governor Tim Walz and told him that the Military is with him all the way. Any difficulty and we will assume control but, when the looting starts, the shooting starts. Thank you!

(1266231100780744704, May 29, 2020, 7:53 AM)

Trump attacked the Minneapolis Mayor, a democrat, by calling him "weak" and lacking "leadership" (tweet 3) for not using force against the protesters. Instead of winning the protesters through reasoning and promises of reform, Trump argued from negative consequences and offered the Minneapolis Mayor into a dichotomization with two options to choose from (tweet 3).

Trump's reference to the protesters as "thugs" is an argumentum ad hominem (tweet 4). In this argument type, the arguer casts doubt on the character of the addressee(s) in order to delegitimize their position. By labeling protesters "thugs", Trump discredited them and legitimized the intervention of the Military. Right after bringing up the Military in the tweet, Trump made a covert ad baculum argument based on an indirect threat in "when the looting starts, the shorting starts". Instead of appealing to positive emotions or addressing protesters' demands, Trump issued a threat about the negative consequences that will follow. Such a threat consists of "a binding order (directive) and a threat (commissive)" (Sahlane, 2015). Following Walton (2000, p. 130; 2014, 287), the inferential process in this argument from threat may be represented as shown in Figure 1.

Premise 1: If you (protesters) do not bring about $A$ (stop looting), some cited bad consequences, $B$ (shooting), will follow.

Premise 2: I am in position to bring about $B$.

Premise 3: I hereby assert that I will see to it that $B$ occurs if you do not bring about $A$.

Conclusion: You had better bring about $A$.

Figure 1. A practical inference of Trump's threat appeal (shooting)

Trump's "past willingness to carry out threats" and his "reputation for truthfulness" makes this appeal to threat credible (Walton, 2000, p. 121). The protesters believe that Trump has the ability to bring about the threat, and his willingness to carry it out is already expressed in the argument from threat. The threat is also legitimate. It has been made by the Commander-in-Chief of the US Army during a national emergency over COVID-19 and amid growing social unrest that is boiling over to other states. Trump's ad baculum argument is fallacious because it argues from negative consequences instead of using rational argumentation. Trump's appeal to threat misfired and Twitter was quick to flag it for violating policies against glorifying violence. Trump's threat incited further violence and defiance among the protesters. Trump attempted to clear up his tweet less than two hours later.

5 Looting leads to shooting, and that's why a man was shot and killed in Minneapolis on Wednesday night - or look at what just happened in Louisville with 7 people shot. I don't want this to happen, and that's what the expression put out last night means. (1266434153932894208, May 29, 2020, 9:20 AM)

6 It was spoken as a fact, not as a statement. It's very simple, nobody should have any problem with this other than the haters, and those looking to cause trouble on social media. Honor the memory of George Floyd! (1266434155543506945, May 29, 2020, 9:20 AM)

Trump's use of an ad baculum argument based on innuendo allowed him to shield himself off from a burden of proof (Walton, 2014) and the fact that threatening is a perlocutionary rather than illocutionary speech act (Nicoloff, 1989) gave him a route for plausible deniability. He denied having 
made the threat, denied commitment to bring about the event in the threat, and claimed to have used it "as a fact" (tweet 6) rather than a declaration of intention. Trump's counter-claim in "I don't want this to happen" (tweet 5), however, is itself an appeal to fear. He substituted an ad baculum argument with ad metum argument, both of which are fallacious. In place of rational argumentation, Trump brought up a fearful scenario in which "a man was shot and killed in Minneapolis" and in Louisville "with 7 people shot" in order to scare protesters into submission. Instead of showing sympathy with the lives lost, Trump 'used' them in an argumentative move aimed at maneuver. This argument from negative consequences is also equally ineffective. Trump spoke to the nation the next day.

I want to express our Nation's deepest condolences and most heartfelt sympathies to the family of George Floyd. Terrible event, terrible errible thing that happened... It is a local situation but we are making it into a federal situation. And it is a Terrible thing. We all saw what we saw. It is very hard to even conceive of anything other than what we did see. It should never happen, should never be allowed to happen a thing like that. But we are determined that justice be served. I spoke to members of the family, terrific people... I understand the hurt, I understand the pain. People have really been through a lot. The family of George are entitled to justice and the people of Minnesota are entitled to live in safety. Law and order will prevail... (1266478323556921344, May 30, 2020, 12:15 AM)

Trump sounded 'presidential' at the start of the speech by expressing the "Nation's deepest condolensces and most heartfelt sympathies" but soon, true to his "fourth- to fifth-grade level" speaking style" (Wang \& Liu, 2018, p. 315) described Floyd's death as "a terrible terrible thing that happened" and said "We all saw what we saw." He promised justice at the end but neither backed out of his previous ad baculum and ad metum arguments nor did he speak about police brutality. On May 30, protesters assembled in a park across from the White House in Washington DC and Trump's "understanding of the pain and hurt" of people is put to the test. His rhetoric soon turned aggressive again in a sequence of tweets:

7 Great job last night at the White House by the U.S. @ SecretService. They were not only totally professional, but very cool. I was inside, watched every move, and couldn't have felt more safe. They let the "protesters" scream \& rant as much as they wanted, but whenever someone... (1266711221191020544, May 30, 2020, 3:41 PM)

8 ...got too frisky or out of line, they would quickly come down on them, hard - didn't know what hit them. The front line was replaced with fresh agents, like magic. Big crowd, professionally organized, but nobody came close to breaching the fence. If they had they would... (1266711221836931072, May 30, 2020, 3:41 PM)

9 ...have been greeted with the most vicious dogs, and most ominous weapons, I have ever seen. That's when people would have been really badly hurt, at least. Many Secret Service agents just waiting for action. "We put the young ones on the front line, sir, they love it, and... (266711223657205763, May 30, 2020, 3:41 PM)

Trump, watching the Secret Service clamp down on protesters, said that he "couldn't have felt more safe" (tweet 7). The protesters are constructed as a threat to his own life and this construction serves to legitimize the use of lethal force against them. This is followed by the veiled threat to protesters. Instead of stepping out to address the concerns and fears of the protesters, Trump threatened to let out "the most vicious dogs" on them and use "the most ominous weapons" (tweet 9). This is a conditional ad baculum agrument (Walton, 2014) which is fallacious because it resorts to threatening the use of force instead of offering persuasive argumentation in order to win the protesters' compliance. This threat is credible, since protesters believe that Trump has the power to make it happen, and legitimate, since it is coming from the President in the White House. In order to further delegitimize the protesters' claims, Trump called into question the character of the protesters themselves who are described as "professionally organized" (tweet 8 ). The construction of protesters as an organized group with an agenda affects their 
reliability (Dahlman, Reidhav, \& Wahlberg, 2013) in demanding justice or police reforms over Floyd's death. Trump extends this ad hominem fallacy in a series of tweets that followed:

10 The professionally managed so-called "protesters" at the White House had little to do with the memory of George Floyd. They were just there to cause trouble. The @ SecretService handled them easily. Tonight, I understand, is MAGA NIGHT AT THE WHITE HOUSE??? (1266724553620930561, May 30, 2020 4:30 PM)

$1180 \%$ of the RIOTERS in Minneapolis last night were from OUT OF STATE. They are harming businesses (especially African American small businesses), homes, and the community of good, hardworking Minneapolis residents who want peace, equality, and to provide for their families. (1266800113260703744, May 30, 2020 9:34 PM)

12 Congratulations to our National Guard for the great job they did immediately upon arriving in Minneapolis, Minnesota, last night. The ANTIFA led anarchists, among others, were shut down quickly. Should have been done by Mayor on first night and there would have been no trouble! (1267124501361369091, May 31, 2020 7:03 PM)

13 LAW \& ORDER! (1267227396341669889, Jun 1, 2020 1:52 AM; Jun 3, 2020 2:19 PM; Jun 4, 2020 1:58 PM; Jun 7, 2020 1:48 AM; 5:19 PM · Jun 15, 2020; 3:23 PM · Jun 13, 2020; 5:21 AM · Jun $11,2020)$

14 Yesterday was a bad day for the Cuomo Brothers. New York was lost to the looters, thugs, Radical Left, and all others forms of Lowlife \& Scum. The Governor refuses to accept my offer of a dominating National Guard. NYC was ripped to pieces. Likewise, Fredo's ratings are down 50\%!

(1267811637811187712) Jun 2, 2020 4:33 PM)

15 If you watch Fake News @CNN or MSDNC, you would think that the killers, terrorists, arsonists, anarchists, thugs, hoodlums, looters, ANTIFA \& others, would be the nicest, kindest most wonderful people in the Whole Wide World. No, they are what they are - very bad for our Country!

(1268166288993632256, Jun 3, 2020 4:02 PM)

16 The problem is not the very talented, low-flying helicopter pilots wanting to save our city, the problem is the arsonists, looters, criminals, and anarchists, wanting to destroy it (and our Country)! (1268678440225583105, Jun 5, 2020 1:58 AM)

Trump delegitimized the protesters' position by demonizing them and heaping negatively connotated words on them. This ad hominem fallacy is carried by over fifteen tweets published in a span of six days. The protesters are "rioters" (tweet 11), "ANTIFA led anarchists" (tweet 12), "looters, thugs, Radical left, and all other forms of Lowlife \& Scum" (tweet 14), "killers, terrorists, arsonists, anarchists, thugs, hoodlums, looters, ANTIFA" (tweet 15), and "arsonists, looters, criminals and anarchists" (tweet 16). Neither Trump nor federal officials had offered conclusive evidence in support of the argument that the protesters were ANTIFA members or led by ANTIFA (Yen, Woodward, \& Seitz, 2020). This "negative overlexicalization" (Sahlane, 2012, p. 463) serves to locate the protesters' rhetoric and activities within a discourse of malignity and textually construct Trump and his actions on the more 'benign' end of the spectrum by presupposition (Fairclough, 2005). Trump accentuated this textual dichotomy by declaring himself the President of Law and Order (tweet 13, published 7 times between June 1 and 11), a frame in which the protesters, in opposition to Trump, represent lawlessness and chaos. The threat that the protesters pose is to Trump's own life (tweet 7) as well as to the "homes, and the community of good, hardworking Minneapolis residents who want peace, equality, and to provide for their families" (tweet 11). This narrative, in which the protesters are "terrorists" (tweet 15) posing an 'existential' threat to the American lives and moral values, aims at mobilizing the public by appealing to their sense of fear for their lives and the Secret Service, Police and the Military by appealing to their 
sense of national duty to protect the President, the U.S. capital and the American people. The next set of tweets criminalize the demonstrations and invite forceful action against them.

17 Crossing State lines to incite violence is a FEDERAL CRIME! Liberal Governors and Mayors must get MUCH tougher or the Federal Government will step in and do what has to be done, and that includes using the unlimited power of our Military and many arrests. Thank you! (1266796670609588225, May 30, 2020 9:20 PM)

18 SO TERRIBLE! Where are the arrests and LONG TERM jail sentences? (1267197835067502592, May 31, 2020 11:54 PM)

19 D.C. had no problems last night. Many arrests. Great job done by all. Overwhelming force. Domination. Likewise, Minneapolis was great (thank you President Trump!). (1267808120136511489, Jun 2, 2020 4:19 PM)

20 Get tough police! (1268132269245464577, 1:47 PM · Jun 3, 2020)

After delegitimizing the demonstrations and criminalizing the actions of protesters (tweet 17), Trump issued yet another disjunctive ad baculum argument by dichotomizing the solution for the Mayors and Governors who have to "get MUCH tougher" or "the Federal Government will step in" and use "the unlimited power of our Military and many arrests" (tweet 17, original emphasis).

Trump made another argument from consequences the next day. He appealed to the protestors' fear of "arrests and LONG TERM jail sentences" (tweet 18, original emphasis) in yet another ineffective, fallacious attempt at persuasion. Trump's argumentation derailed again two days later into a fallacious argument when he appealed to the protesters' fear of the use of "overwhelming force" (tweet 19). This list concludes with a direct speech act in which Trump orders the police, against whose brutality the protests started in the first place, to "get tough" on the protesters (tweet 20). This appeal to the African Americans' psychological fear of the use of force by the police is fallacious by all counts. In addition to sidelining logical reasoning, Trump, the President of the United State, directed the police to get tough and use force, which would only create further division and inflame further tension.

The ineffectiveness of Trump's argumentative moves in addressing the protesters' concerns lead him to take on a 'more familiar' opponent - the media. This is a derailment in his argumentation in response to the nationwide protests. He sought to destroy the credibility of the press covering the protests and construct the media outlets as co-perpetrators of the ongoing chaos (tweets 21 to 23 below).

21 Much more “disinformation” coming out of CNN, MSDNC, @ nytimes and @ washingtonpost, by far, than coming out of any foreign country, even combined. Fake News is the Enemy of the People! (1266799941273350145, May 30, 2020 9:33 PM)

22 The Lamestream Media is doing everything within their power to foment hatred and anarchy. As long as everybody understands what they are doing, that they are FAKE NEWS and truly bad people with a sick agenda, we can easily work through them to GREATNESS! (1267132763116838913, May 31, 2020 7:36 PM)

23 So pathetic to watch the Fake News Lamestream Media playing down the gravity and depravity of the Radical Left, looters and thugs, ripping up our Liberal Democrat run (only) cities. It is almost like they are all working together? (1268037166946553856, Jun 3, 2020 7:29 AM)

Because the media offered an account of the ongoing events that was not aligned with Trump's narrative, he attempted to coercively silence the press by calling into question not only the credibility of the "CNN, MSDNC, @ nytimes and @ washingtonpost" spreading "misinformation" and "FAKE NEWS" (tweet 21, original emphasis) but also their allegiance to the country and the people. He calls 
them "the Enemy of the People" (tweet 21), accuses them of fomenting "hatred and anarchy" (tweet 22 ), and constructing them as accomplices in the looting (tweet 23). These claims are not backed by evidence and were deployed to cast suspicion on the (national) motives of the media. Trump's strategic maneuvering here is also fallacious because it aims at blocking argumentation by attacking the motives of the other party. This fallacy is known in the literature as circumstantial ad hominem (Dahlman, Reidhav, \& Wahlberg, 2013). Trump's strategic maneuvering does not stop here. He further politicized the situation by taking on his democratic opponents. The attack on the democrats will be analyzed under three themes: casting suspicion on the reliability of democratic Mayors and Governors (tweets 24-29), direct personal attack on the presumptive democratic presidential nominee Joe Biden (tweets 30-35), and the "defund the police" proposal (tweets 36-43).

24 Time for a change! \#2020 (1266570099454103553, May 30, 2020 6:20 AM)

25 Mayor Jacob Frey of Minneapolis will never be mistaken for the late, great General Douglas McArthur or great fighter General George Patton. How come all of these places that defend so poorly are run by Liberal Democrats? Get tough and fight (and arrest the bad ones). STRENGTH (1266737385120960515, May 30, 2020 5:25 PM)

26 The National Guard has been released in Minneapolis to do the job that the Democrat Mayor couldn't do. Should have been used 2 days ago \& there would not have been damage \& Police Headquarters would not have been taken over \& ruined. Great job by the National Guard. No games! (1266914470066036736, May 31, 2020 5:08 AM)

27 Get tough Democrat Mayors and Governors. These people are ANARCHISTS. Call in our National Guard NOW. The World is watching and laughing at you and Sleepy Joe. Is this what America wants? NO!!! (1267187902192193538, May 31, 2020 11:15 PM)

$28 @$ MayorBowser is grossly incompetent, and in no way qualified to be running an important city like Washington, D.C. If the great men and women of the National Guard didn't step forward, she would have looked no better than her counterpart Mayor in Minneapolis! (1269043981461184514, Jun 6, 2020 2:10 AM)

29 Domestic Terrorists have taken over Seattle, run by Radical Left Democrats, of course. LAW \& ORDER! (1270923257844301836, Jun 11, 2020 6:38 AM)

Trump kicked off the series of tweets by appealing to the electorates' sense of partisan solidarity (tweet 24) directed at the democratic leaders in Minneapolis (the Mayor, Governor, Secretary of State, State Auditor, Sr and Jr US Senators, and Chief Police). He accused the Minneapolis Mayor (tweet 25) and the Washington D. C. Mayor (tweet 27) of defending poorly and ordered them to "get tough and fight (tweets 25, 27). He constructed the situation as a fight in which the protesters attack "Democrat run (only) cities" (tweet 23) and the Mayors have to "defend" and "fight" back with "STRENGTH" (tweet 25). He called in the National Guard to end the "games" the democrats had been playing (tweet 26) three days before he accused them of "working together" with the "looters and thugs" (tweet 23, above). This list of tweets ends with another ad hominem fallacy in which Trump attacked the democratic leaders of Seattle with little evidence in support of the argument. In fact, reports suggest that the Seattle police withdrew from certain blocks to allow protesters to set up "a festive scene with speeches, activism, art and music" which were largely peaceful (Yen, H., Woodward, C., and Seitz, A., 2020). Trump's demonization of the protesters who he called "domestic terrorists" taking over Seattle (tweet 29) and his direct personal attack on the presumptive democratic presidential nominee Joe Biden (tweets 30 to 35) is an extension of the ad hominem argument. 
30 Law \& Order in Philadelphia, NOW! They are looting stores. Call in our great National Guard like they FINALLY did (thank you President Trump) last night in Minneapolis. Is this what voters want with Sleepy Joe? All Dems! (1267185107980496896, May 31, 2020 11:04 PM)

31 "These were the people that trashed Seattle years ago. Who's paying for these people. I was appalled that 13 of Joe Biden's staff were donating money to bail people out in Minneapolis. They should have stayed in jail until this is over (and beyond).”@ @ewtgingrich @ foxandfriends (1267432507005448192, Jun 1, 2020 3:27 PM)

32 Sleepy Joe has been in politics for 40 years, and did nothing. Now he pretends to have the answers. He doesn't even know the questions. Weakness will never beat anarchists, looters or thugs, and Joe has been politically weak all of his life. LAW \& ORDER! (1267907954537312256, Jun 2, 2020 10:56 PM)

33 In 3 1/2 years, I've done much more for our Black population than Joe Biden has done in 43 years. Actually, he set them back big time with his Crime Bill, which he doesn't even remember. I've done more for Black Americans, in fact, than any President in U.S. history, with the possible exception of another Republican President, the late, great, Abraham Lincoln...and it's not even close. The Democrats know this, and so does the Fake News, but they refuse to write or say it because they are inherently corrupt! See "pinned" above. (1268167411230007300, Jun 3, 2020 4:07 PM)

34 Colin Powell, a real stiff who was very responsible for getting us into the disastrous Middle East Wars, just announced he will be voting for another stiff, Sleepy Joe Biden. Didn't Powell say that Iraq had "weapons of mass destruction?" They didn't, but off we went to WAR! (1269634983687315457, Jun 7, 2020 5:19 PM)

35 Sleepy Joe Biden refuses to leave his basement "sanctuary" and tell his Radical Left BOSSES that they are heading in the wrong direction. Tell them to get out of Seattle now. Liberal Governor @ JayInslee is looking “the fool”. LAW \& ORDER! (1271080249623818242, Jun 11, 2020 5:02 PM)

Trump's tweets on presumptive democratic presidential nominee Joe Biden are a clear instance of derailment in strategic maneuvering in argumentative discourse. The derailment manifests itself in the "poisoning the well" fallacy directed at Joe Biden. This argument types, according to Walton (2006), has a "diffusion effect because it does not merely refute the proponent's argument, it destroys his capability for putting forward any argument on the same topic" (p. 292). After declaring that the democrats are "working together" with the "looters and thugs" (tweet 23, above), Trump tweeted that Biden's staff had been bailing prisoners out of Minneapolis jails to extend the chaos (tweet 31). Trump's aim was to frame Biden as a perpetrator who is disqualified from discussing any resolutions to the current crisis. To further disqualify Biden from "putting forward any argument on the same subject, or perhaps even any argument on any subject, in the future discussion" (Walton, 2006, p. 292), Trump resorted to personal defamation by calling Joe Biden "Sleepy Joe" (tweets 27, 30, 32, 34 and 35). Namegiving is an "assertive communicative behaviour" that stigmatizes an opponent in a way that they can do little to change because the nicknames "need not be justified, neither can they be contradicted or disproved" (Sornig, 1989, p. 100). Trump continued to defame Biden by saying that Biden "has been in politics for 40 years, and did nothing", describing him as "politically weak" (tweet 32), and claiming the he (Trump) had done in three and a half years for the "Black" population more than Biden had done in 43 years (tweet 33). To this list of stigmatizing depictions, Trump added "stiff" (tweet 34). He called Collin Powell "a real stiff" who will be voting for "another stiff" (Sleepy Joe Biden) and reminded the electorates of Powell's 'lie' about Iraq's weapons of mass destruction and the wrong decision of taking America to "WAR" (tweet 34, original emphasis). The tweet discredits Collin Powell but the faulty analogy is meant to disqualify his presidential nominee by implication and scare the electorates about the prospects of war should Biden get elected. The las set of tweets also invoke Biden but take us back to the police whose unchecked brutality triggered the social unrest (tweets 36 to 43). 
36 The Radical Left Democrats new theme is "Defund the Police". Remember that when you don't want Crime, especially against you and your family. This is where Sleepy Joe is being dragged by the socialists. I am the complete opposite, more money for Law Enforcement! \#LAWANDORDER (1268635752214208514, Jun 4, 2020 11:08 PM)

37 Sleepy Joe Biden and the Radical Left Democrats want to "DEFUND THE POLICE". I want great and well paid LAW ENFORCEMENT. I want LAW \& ORDER! (1269617458354282502, Jun 7, 2020 4:09 PM)

38 Not only will Sleepy Joe Biden DEFUND THE POLICE, but he will DEFUND OUR MILITARY! He has no choice, the Dems are controlled by the Radical Left. (1269630609883910144, Jun 7, 2020 5:01 PM)

39 LAW \& ORDER, NOT DEFUND AND ABOLISH THE POLICE. The Radical Left Democrats have gone Crazy! (1269970808329437185, Jun 8, 2020 3:33 PM)

40 This year has seen the lowest crime numbers in our Country's recorded history, and now the Radical Left Democrats want to Defund and Abandon our Police. Sorry, I want LAW \& ORDER! (1270018789250400257, Jun 8, 2020 6:44 PM)

41 "Defunding Police would be good for Robbers \& Rapists." @ SenBillCassidy (1270360886297989120, Jun 9, 2020 5:23 PM)

42 "Democrats \& Activists call to Defund Police Departments. They've gone so far Left that they eat their young.” @ mirandadevine @ nypost @foxandfriends (1270325223242506241, Jun 9, 2020 3:01 PM)

43 The Radical Left Democrats: First they try to take away your guns. Then they try to take away your police! (1271252020473638912, Jun 12, 2020 4:24 AM)

Intensifying his war against the "Radical Left Democrats" (tweets 36, 37, 38, 39, 40, 43), Trump seized on popular calls to "defund the police" and falsely attributed them to "Sleepy Joe" (tweets 36, 37,38 ) as he "fights for momentum amid crises that threaten his reelection" (Peoples, Farm, \& Lemire, 2020). In addition to committing this fallacy of false attribution (Dahlman, Reidhav, \& Wahlberg, 2013, p. 63), Trump made a series of appeals to fear arguments that aim at manipulating electorates' beliefs and changing their voting behavior. He invoked the fearful scenario where crime is prevalent, threatening the lives of Americans and their families (tweets 36,40), described the terrible consequences for the police and the Military of electing Joe Biden (tweet 37, 38, 39), and labelled that 'possible world' as one that is good for "Robbers \& Rapists" (tweet 41, original case). Trump's arguments are fallacious because they appeal to the discourse recipients' natural fear for their lives and the lives of their loved ones instead of presenting reliable evidence in the interest of personal gains. They are also not true as Joe Biden denies supporting defunding the police, let alone 'abolishing the police' (tweet 39) or 'defunding the military' (tweet 38). In an interview with CBC, Biden asserts, instead, his support for "conditioning federal aid to police based on whether or not they meet certain basic standards of decency and honorableness.....and demonstrate they can protect the community and everybody in the community" (Bradner, Mucha, \& Judd, 2020).

Trump also constructed a textual opposition between his theme of 'law and order' and the democrats' alleged "defund the police" theme (tweet 39). In this frame, the democrats are calling for lawless and anarchy, in textual opposition to his own calls for law and order. A few hours later, Trump added yet another appeal for fear (tweet 40) in which he tried to scare the electorates with the fearful outcome of crime numbers increasing should democrats have it their way. This fear appeal argument is also fallacious because it is based on false evidence since the crime numbers for 2020 have not been compiled and "FBI statistics show the violent crime rate was lower in 2014 than in 2018, the most recent year 
recorded" (Yen, Woodward, \& Seitz, 2020). In his last tweet in this context (tweet 43), Trump twisted a popular metaphor about liberal democrats who challenge their own standards to "improve conditions for the future" (Elisberg, 2011) to force it into the 'defund' argument by suggesting that democrats are betraying the police. Finally, and after a series of arguments in which Trump failed to confess to the existence of racism and address it directly, he made a speech, re-tweeted by the White House account @ WhiteHouse, in which he declared that his administration was working on an Executive Order to "encourage police departments nationwide to meet the most current professional standards for the use of force, including tactics for de-escalation" (tweet 44).

44 "We're working to finalize an Executive Order that will encourage police departments nationwide to meet the most current professional standards for the use of force, including tactics for de-escalation." (1271194512434618374, Jun 12, 2020 12:36 AM)

\section{Conclusions}

Analysis has revealed that Trump's argumentation in response to the protests is essentially argumentation from consequences in which persuasion yields to scare tactics. Trump's argumentative discourse derails into a set of fallacious arguments including fear appeal arguments (appealing to the audience's emotion of fear for their lives by labelling protesters "terrorists" and alluding to the prospect of prevalent crime), threat appeal arguments (such as threatening the use of the unlimited power of the Military against the demonstrators to force them into submission), framing the demonstrators by heaping negative lexical variants that trigger a host of negative cognitive connotations in order to legitimize the use of force (van Dijk, 2002), and politicizing the argument by summoning his archrivals the press and the democrats, who are stigmatized and constructed as a threat to the nation, in order to gain momentum in a derailing argumentation.

Trump's tweets aggravated the social unrest by invoking racist comments and statements in the midst of the nationwide social unrest about racism. The key statement "when the looting starts, the shooting starts" dates back to the Police Chief of Miami Walter Headley who used it in 1967 in response to the outbreak of riots in response to 'unchecked police brutality'. Headley accused young 'hoodlums' of the rioting, threatened that the black community "would henceforth receive concentrated treatment with double patrols armed with shotguns and dogs" (Lithwick, 2020). Based on the similarity in the two contexts, as well as in the rhetoric including "hoodlum" and "dogs", the study concludes that Trump deliberately invoked this racist discourse in response to a contextually similar revolt.

This paper has focused almost exclusively on arguments published on Twitter - a microblogging tool with a 280-character count limit on tweets. Argumentation in online communication is different than the more traditional forms of argumentation. One difference is the brevity of the posts or tweets and the concomitant effects of reduced message size on linguistic and rhetorical structure. In addition to carefully editing the content, authors in online communication use simplified punctuation, reduced sentence length, less subordination, and other character-conserving styles of writing in order to meet the space limit constraints (Crystal, 2011). Another difference is that users in online communication strive to generate effect even if this is achieved at the cost of engaging in flame wars (Alonzo and Aiken, 2004). It will be interesting for future research in the area to examine the impact of digital technology on the linguistic and affective aspects of argumentation in Web 2.0 contexts, especially in the argumentative discourse of Donald Trump. 


\section{Ethics Committee Approval}

The author(s) confirm(s) that the study does not need ethics committee approval according to the research integrity rules in their country (Date of Confirmation: July 17, 2020).

\section{References}

Alonzo, M., \& Aiken, M. (2004). Flaming in electronic communication. Decision Support Systems, 36(3), 205-213.

Austin, J. (1961). How to do things with words . New York: Oxford University Press .

Bradner, E., Mucha, S., \& Judd, D. (2020, June 8). Biden says he doesn't support defunding police. Retrieved on June 18, 2020 from https://edition.cnn.com/2020/06/08/politics/joe-biden-defund-thepolice/index.html

Clark, I., \& Grieve, J. (2019). Stylistic variation on the Donald Trump Twitter account: A linguistic analysis of tweets posted between 2009 and 2018. PLoS ONE, 14(9), 1-27.

Crystal, D. (2011). Internet linguistics: A student guide. London: Routledge.

Dahlman, C., Reidhav, D., \& Wahlberg, L. (2013). Fallacies in ad hominem arguments. In Dahlman, C. (Ed.), Legal Argumentation Theory: Cross-disciplinary Perspectives (pp. 57-70). Law and Philosophy Library Springer.

Eemeren, F., \& Grootendorst, R. (1992). Argumentation, communication, and fallacies: A pragmadialectical perspective. New York: Lawrence Erlbaum Associates, Publishers.

Eemeren, F., \& Grootendorst, R. (2004). A Systematic theory of argumentation: The para-dialectical approach. Cambridge: Cambridge University Press.

Elisberg, R. (2011, May 25). When democrats eat their young. Retrieved on June 1, 2020 from https://www.huffpost.com/entry/when-democrats-eat-their_b_407112

Fairclough, Norman. (2005). Blair's contribution to elaborating a new 'Doctrine of International Community.' Journal of Language and Politics, 40(1), 41-63.

Golshan, T. (2016, October 19). Donald Trump's strange speaking style, as explained by linguists. Retrieved on June 3, 2020 from https://www.vox.com/2016/8/18/12423688/donald-trump-speechstyle-explained-by-linguists

Hall, K., Goldstein, D. M., \& Ingram, M. B. (2016). The hands of Donald Trump: Entertainment, gesture, spectacle. Journal of Ethnographic Theory, 6(2), 71-100.

Kayam, O. (2018). The readability and simplicity of Donald Trump's language. Political Studies Review, 16(1), 73-88.

Lithwick, D. (2020, May 29). Whether the President understands the racist history of "looting and shooting" is beside the point. Retrieved on June 7, 2020 from https://slate.com/news-andpolitics/2020/05/trump-looters-shooters-racism.html

Monggong, L. (2017, July). Language and culture in the case of Merriam-Webster's correction over President Trump's tweets. Presentation at the International Seminar on Language Maintenance and Shift. Semarang, Indonesia.

Nicoloff, F. (1989). Threats and illocutions. Journal of Pragmatics, 13(4), 501-522. 
Ott, B. L. (2017). The age of Twitter: Donald J. Trump and the politics of debasement. Critical Studies in Media Communication, 34(1), 59-68.

Peoples, S., Farm, A., \& Lemire, J. (2020, June 9). Key democrats spurnpPush to defund police amid Trump attacks. Retrieved on June 15, 2020 from https://www.usnews.com/news/politics/articles/2020-06-09/key-democrats-spurn-push-to-defundpolice-amid-trump-attacks

Robinson, D. (2019, August 09). Text analysis of Trump's tweets confirms he writes only the (angrier) Android half. Retrieved on June 5, 2020 from http://varianceexplained.org/r/trump-tweets/

Sahlane, A. (2015). Dialectics of argument and rhetoric: Protesting the Iraq war in US-British opinion press. Discourse \& Society, 26(6), 1-21.

Sahlane, A. (2012). Argumentation and fallacy in the justification of the 2003 war on Iraq. Argumentation 26(4), 459-488.

Salmon, M. H. (2013). Introduction to logic and critical thiking . Boston: Wadsworth, Inc.

Searle, J. (1970). Speech acts: An essay in the philosophy of language. Cambridge: Cambridge University Press .

Sornig, Karl. (1989). Some remarks on linguistic strategies of persuasion. In R. Wodak (Ed.), Language, power and ideology: Studies in political discourse (pp. 95-113). Amsterdam/Philadelphia: John Benjamins Publishing Company.

van Dijk, T. (2002) Political discourse and political cognition. In P. Chilton \& C. Schäffner (Eds.), Politics as text and talk: Analytic approaches to political discourse (pp. 203-237). Amsterdam/Philadelphia: John Benjamins Publishing Company.

Walton, D. (2014). A dialectical analysis of the ad baculum fallacy. Informal Logic, 34(4), 276-310.

Walton, D. (2006). Poisoning th well. Argumentation, 20(3), 273-307.

Walton, D. (2000). Scare tactics: Arguments that appeal to fear and threats. University of Alabama Press . Springer Netherlands: Springer Science+Business Media B.V.

Wang, Y., \& Liu, H. (2018). Is Trump always rambling like a fourth-grade student? An analysis of stylistic features of Donald Trump's political discourse during the 2016 election. Discourse and Society, 29(3), 299-323.

Wodak, R. (2015). Political Argumentation. In G. Mazzoleni (Ed.), The International encyclopedia of political communication (pp. 43-52). New Jersey: Wiley-Blackwell.

Yen, H., Woodward, C., \& Seitz, Amanda. (2020, June 13). AP FACT CHECK: Trump's law and order and misinformation. Retrieved on June 23, 2020 from https://www.pbs.org/newshour/politics/apfact-check-trumps-law-and-order-and-misinformation 


\section{Yağma, ateş etmeye yol açar: Başkan Trump'ın Floyd'un ölümü hakkındaki tartışmacı söyleminin pragma-diyalektik analizi}

\section{$\ddot{O} \mathbf{z}$}

$\mathrm{Bu}$ çalışma, George Floyd'un öldürülmesi üzerine protestocuların adalet, ırksal eşitlik ve polis reformları taleplerine yanıt olarak Başkan Trump'ın argümantasyonunu sorunsallaştırmayı amaçlamaktadır. İlk tepkisinde Trump, öfkeli kalabalığı hayal kırıklığına uğratan ve harekete geçiren hafif bir retorik kullandı. Artan protestolara yanıt olarak, Trump kendi söylemini tırmandırdı. Protestocuların karakterini ve güvenilirliğini sorgulayan Trump, protestocuları "haydutlar" ve "teröristler" olarak etiketledi, ordunun konuşlandırılmasına atıfta bulundu ve "yağma başladığında ateş başlar" tweet'ledi. Trumps'ın yanıtının pragma-diyalektik analizi, rasyonel argümantasyonun isim verme, ad baculum ve ad hominem yanılgılarını içeren stratejik manevraları raydan çıkardığını ortaya koyuyor. Trump, gösterileri zorla durdurmak ve itaati güçlendirmek için ikna edici mantıktan korku uyandırmaya ve tehdit etme taktiklerine diyalektik bir geçiş yapıyor ve daha sonra ikna etmekten eristik söyleme geçiş yapıyor. Medyayı nefret ve anarşiyi kışkırtmakla ve kargaşayı alay edilen ve kişisel olarak istismara uğrayan demokratik rakibini suçlayarak tepkisini siyasallaştırıyor. Bunlar sosyo-politik bağlamda olduğu kadar ikna söylemi bağlamında da alakasız tartışmacı hareketlerdir.

Anahtar Sözcükler: argümantasyon; Donald J. Trump; yanlışlıklar; Floyd; Twitter

\section{AUTHOR BIODATA}

Gibreel Sadeq Alaghbary (g.alaghbary@qu.edu.sa) is an assistant professor of English at the Department of English, College of Sciences and Arts, Unaizah, Qassim University in Saudi Arabia. He is also an associate professor of English at the Center for Languages and Translation, Taiz University, Yemen. He served as a Fulbright post-doctoral fellow and adjunct faculty at San Diego State University, USA, in 2013. His research covers the analysis of textual ideology with a focus on political discourse. He is author of Ideological Positioning in Conflict in the Routledge Handbook of Language in Conflict, 2019. 